\title{
Synthetic Resveratrol Derivatives and Their Biological Activities: A Review
}

\author{
Ya Liu1,2*, Yi Liu1,2*, Hongfei Chen1,2, Xu Yao1,2, Yan Xiao',2, Xianliang Zeng1,2, \\ Qutong Zheng1,2, Yun Wei1,2, Chen Song1,2,3, Yinxiang Zhang1,2,3, Peng Zhu',2,3, \\ Juan Wang1,2\#, Xing Zheng1,2\# \\ ${ }^{1}$ University of South China, Hengyang, China \\ ${ }^{2}$ Hunan Province Cooperative Innovation Center for Molecular Target New Drug Study, Hengyang, China \\ ${ }^{3}$ Research Interest Group, University of South China, Hengyang, China \\ Email:"pharmacynhu@sohu.com, "drxzheng@yahoo.com
}

Received 6 November 2015; accepted 5 December 2015; published 9 December 2015

Copyright (C) 2015 by authors and Scientific Research Publishing Inc.

This work is licensed under the Creative Commons Attribution International License (CC BY). http://creativecommons.org/licenses/by/4.0/

(c) (j) 0pen Access

\section{Abstract}

Resveratrol, a naturally derived stilbene that exists in various foods and beverages, has attracted extensive exploration due to its multiple biological activities, such as anticancer, antioxidant, cardiovascular protection, anti-inflammatory, antiviral, chemopreventive effect, neuroprotective effect, immunomodulation and so on. However, owing to its poor oral bioavailability, the application of resveratrol is greatly restricted. Because of that, a large amount of efforts had been made by researchers on designing its derivatives to obtain compounds with improved efficiency and low toxicity for developing more active drugs for clinical application. In this report, we review the current development of studying on resveratrol derivatives including their properties and activities. Additionally, this article also presents the synthetic routes of correlative resveratrol derivatives.

\section{Keywords}

Anticancer, Antioxidant, Anti-Inflammatory, Resveratrol Derivatives, Structure-Activity Relationship (SAR)

\section{Introduction}

Resveratrol (trans-3, 4', 5-trihydroxystilbene) is naturally present in certain fruits and plants, including grapes, peanuts and mulberries, in response to stress, injury, ultraviolet irradiation and fungal infection [1] [2]. This

${ }^{*}$ These two authors contributed equally to this article.

${ }^{\#}$ Corresponding author. 
compound, which could cause the so-called "French paradox" [3] [4], was first isolated from the roots of the white hellebore (Veratrum grandiflorum O. Loes) in 1940 [5]. However, it began to attract worldwide attention in 1992 because of the discovery of its cardioprotective activity [6].

Resveratrol is one of the best characterized stilbenes and is known to possess a wide range of biological activities including anticancer [7] [8], antioxidant [9] [10], cardiovascular protection [11] [12], anti-inflammatory [13], antiviral [14] [15], antimicrobial [16], chemopreventive effect [17] [18], neuroprotective effect [19] [20] and immunomodulation activity [21]. Resveratrol was also used as herbal medicine in China and other East Asian countries. Nowadays, owing to its multiple bioactivities, more and more attention is being drawn to resveratrol (Figure 1).

However, the potential application of resveratrol is greatly limited due to its rapid metabolism and low solubility, especially the poor water solubility. It is reported that resveratrol was mainly metabolized to its glucuronide metabolite in the small intestine of rat [3] [22]. But in human plasma, resveratrol sulfate was found to be the major metabolite upon oral ingestion of resveratrol [3] [23]. Some reports investigated the absorption, metabolism, and bioavailability of resveratrol by administering 14C-resveratrol to human subjects, confirming the findings that resveratrol was metabolized quickly and extensively [23] [24]. Metabolism is thought to be the main limiting factor for the bioavailability of resveratrol and bioavailability is a key issue on considering potential biological effects in vivo. For this, a large amount of efforts had been made by researchers on designing its derivatives to obtain compounds with improved efficiency and low toxicity to develop more active drugs for clinical application. Meanwhile, the multiple biological activities and action mechanisms of resveratrol have been extensively investigated.

The resveratrol's biological activity and its affinity toward a large variety of molecular targets have been reported in several excellent articles. This article summarizes current development of studying on resveratrol derivatives. Additionally, the basic information, relevant to synthesis of its derivatives, has also been present in this article.

\section{Synthesis of Resveratrol Derivatives with Anticancer Activity}

Some reports had found that resveratrol could interfere in the nuclear factor (NF)- $\kappa$ B signaling pathway, which regulates the expression of various genes involved in cancer and inflammation [7] [25] [26]. Some studies also indicated that the anticancer effect of resveratrol was mediated by inhibiting key proteins in signal transduction pathways such as mitogen-activated protein kinases, activator protein-1 (AP-1), and NF- $\kappa \mathrm{B}$ [3]. Resveratrol could also affect cell-cycle regulation and apoptosis [27]. The mentioned results suggested that resveratrol could be developed to be an effective cancer chemoprevention and therapeutics agent. Owing to resveratrol's extremely poor bioavailability, many scientists have applied themselves to searching for novel resveratrol derivatives with high efficiency, low toxicity, and minimum side effects. Herein, some studies of the structural modifications were given to help understand the structure-activity relationships (SAR) of its anticancer activity better.

Minutolo et al. [28] compared the biological effects of seven naphthalene-based and/or methoxylated resveratrol analogues with resveratrol. They found that compound 3 (Scheme 1) exerts an antiproliferative effect via a ceramide-mediated proapoptotic mechanism, with an increase of endogenous ceramide coupled to cleavage of PARP (poly-(ADP-ribose)-polymerase). In addition, they considered that the compound with a naphthalene ring and three hydroxyls is the most effective in human cancer cells.<smiles>Oc1ccc(/C=C/c2cc(O)cc(O)c2)cc1</smiles>

1

Figure 1. Resveratrol. 
In order to obtain more information about the SAR of resveratrol derivatives, Ruan et al. [29] synthesized a total of 17 resveratrol derivatives. Among which, 13 compounds were reported for the first time. Compared with 5-fluorouracil, they found that compounds 4-7 (Scheme 2) showed strong anticancer activities in vitro. Especially compound $\mathbf{6}$, with an $\mathrm{IC}_{50}$ value of $3.9 \mu \mathrm{M}$, exhibited the most potent activity against human nasopharyngeal epidermoid tumor cell line KB. They assumed that the Br-atom may play the most important role and they found that the replacement of the -OH groups of these derivatives resulted in cytotoxic activities increased.

A novel series of trans-N-phosphoryl amino acid modified resveratrol analogues were synthesized by Liu et al. [30]. They tested the cytotoxic activity of these derivatives against CNE-1 and CNE-2 cell lines. The results indicated that compounds 15a-15d (Scheme 3) displayed much stronger inhibition effect than resveratrol (52.28 \pm $4.90 \mu \mathrm{M}$ ). Especially 15a showed the most potent activity with $\mathrm{IC}_{50}$ value of $3.45 \pm 0.82 \mu \mathrm{M}$. The medical chemists obtained several structure-activity relationships on the basis of all synthetic trans-N-phosphoryl amino acid modified resveratrol analogues as followed: 1) the methoxy groups at 3- and 5-positions of benzene ring played a key role on inhibition activity; 2) The cytotoxicity of these compounds is relevant to the length of the alkyl chain on the N-phosphoryl amino acid moiety; 3) The steric effect of the amino acid may affect the anti-proliferative activity of these resveratrol derivatives.

Liu et al. [31] synthesized several analogues of resveratrol and screened them against a series of human cancer cell lines including RL95-2, SKOV-3, MCF-7 and T-47D in vitro. They found that 3-methoxy-E-diethylstilbestrol and its derivatives (16 and 17) exhibited higher potential anti-tumor activities than compound $\mathbf{1 8 .}$ Therefore, they assumed that the double bond of E-3-methoxystilbestrol (18) is not indispensible for its antitumor activity (Scheme 4)

In order to improve the bioavailability and anticancer activity of resveratrol, Mulakayala et al. [7] synthesized two derivatives of resveratrol and evaluated their activity on U937 cells. Among the two synthetic resveratrol derivatives, the researchers found that the analogues of resveratrol (19 and 20) showed higher rates of inhibition than the parental molecule at $10 \mu \mathrm{M}$ concentration. The results suggested that the allyl groups added to $\mathbf{1 9}$ by substituting the three hydroxyl groups has shown more potent activity. This is perhaps as a result of increasing<smiles>COc1cc(OC)cc(-c2ccc3cc(O)ccc3c2)c1</smiles><smiles>Oc1cc(O)cc(-c2ccc3cc(O)ccc3c2)c1</smiles>

Scheme 1. Synthesis of methoxylated and/or naphthalene-based resveratrol analogues according to Minutolo et al. (2005).<smiles>Oc1ccc(/C=C/c2cc(O)cc(O)c2)cc1</smiles>

1<smiles>[N+]#[N+][Mg]</smiles>

$$
\begin{array}{lll}
4 \mathrm{R}_{1}=\mathrm{BrCH}_{2} \mathrm{CH}_{2}, \mathrm{R}_{2}=\mathrm{BrCH} \mathrm{CH}_{2}, & \mathrm{R}_{3}=\mathrm{BrCH}_{2} \mathrm{CH}_{2} \\
5 \mathrm{R}_{1}=\mathrm{BrCH}_{2} \mathrm{CH}_{2}, \mathrm{R}_{2}=\mathrm{H}, & \mathrm{R}_{3}=\mathrm{H} \\
6 \mathrm{R}_{1}=\mathrm{H}, & \mathrm{R}_{2}=\mathrm{H}, & \mathrm{R}_{3}=\mathrm{BrCH}_{2} \mathrm{CH}_{2} \\
7 \mathrm{R}_{1}=\mathrm{BrCH}_{2} \mathrm{CH}_{2}, \mathrm{R}_{2}=\mathrm{BrCH}_{2} \mathrm{CH}_{2}, \mathrm{R}_{3}=\mathrm{H}
\end{array}
$$

Scheme 2. Synthesis of compounds 4-7 (yield 24\% - 49\%) according to Ruan et al. (2006). 


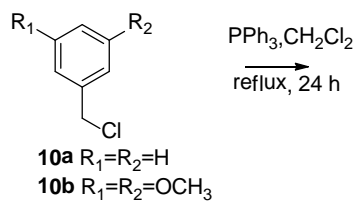

NaH, 4-nitrobenzaldehyde<smiles>[R]c1cc([R])cc(/C=C/c2ccc([N+](=O)[O-])cc2)c1</smiles>

11a $\mathrm{R}_{1}=\mathrm{R}_{2}=\mathrm{H}$

11b $\mathrm{R}_{1}=\mathrm{R}_{2}=\mathrm{OCH}_{3}$

12a $(Z, E) \mathrm{R}_{1}=\mathrm{R}_{2}=\mathrm{H}$

$12 \mathrm{~b}(Z, E) \mathrm{R}_{1}=\mathrm{R}_{2}=\mathrm{OCH}_{3}$

13a $\mathrm{R}_{1}=\mathrm{R}_{2}=\mathrm{H}$ 13b $\mathrm{R}_{1}=\mathrm{R}_{2}=\mathrm{OCH}_{3}$<smiles>[R]c1cc([R])cc(C=Cc2ccc(N)cc2)c1</smiles>

14a $\mathrm{R}_{1}=\mathrm{R}_{2}=\mathrm{H}$

14b $\mathrm{R}_{1}=\mathrm{R}_{2}=\mathrm{OCH}_{3}$
HOBt, DCC THF, r.t. $24 \mathrm{~h}$<smiles>[R]Nc1ccc(/C=C/c2cc([R])cc([R])c2)cc1</smiles>

15a $\mathrm{R}_{1}=\mathrm{R}_{2}=\mathrm{OCH}_{3}, \mathrm{R}=-\mathrm{CO}\left(\mathrm{CH}_{2}\right)_{4} \mathrm{NH}$-DIPP 15b $\mathrm{R}_{1}=\mathrm{R}_{2}=\mathrm{OCH}_{3}, \mathrm{R}=-\mathrm{CO}\left(\mathrm{CH}_{2}\right)_{5} \mathrm{NH}-\mathrm{DIPP}$ 15C $\mathrm{R}_{1}=\mathrm{R}_{2}=\mathrm{OCH}_{3}, \mathrm{R}=$-L-PrO-DIPP

15d $\mathrm{R}_{1}=\mathrm{R}_{2}=\mathrm{H}, \quad \mathrm{R}=-\mathrm{CO}\left(\mathrm{CH}_{2}\right)_{4} \mathrm{NH}-\mathrm{DIPP}$

Scheme 3. Synthesis of compounds 15a-15d (yield 61\% - 73\%) according to Liu et al. (2008).
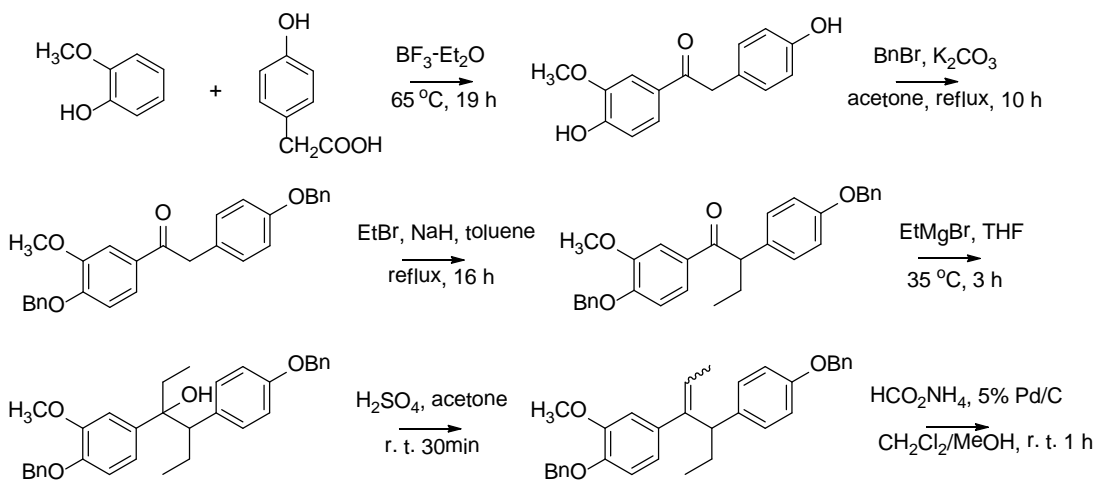<smiles>CC=C(c1ccc(O)c(OC)c1)C(CC)c1ccc(O)cc1</smiles>

16<smiles>CCC(c1ccc(O)cc1)C(CC)c1ccc(O)c(OC)c1</smiles>

17
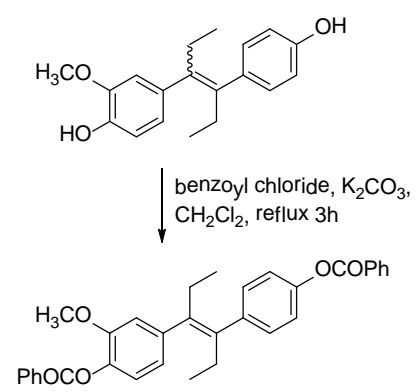

$30 \% \mathrm{NaOH}, \mathrm{CH}_{2} \mathrm{Cl}_{2}$ $\mathrm{EtOH}$, reflux $12 \mathrm{~h}$

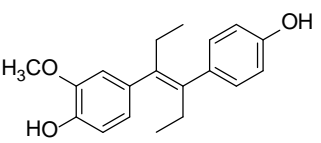

18

Scheme 4. Synthesis of compounds 16-18 (yield 40.5\% - 62.7\%) according to Liu et al. (2012). 
of the half-life period and bioavailability of the compound (Scheme 5).

Szaefer et al. [32] synthesized O-methylated resveratrol derivatives and tested their cytotoxicity on $\mathrm{HaCaT}$ cells. The activity of 3-methoxy-4-methylthio-trans-stilbene (21) was significantly lower $\left(\mathrm{IC}_{50}=182.66 \pm 38.71\right.$ $\mu \mathrm{M})$ than that of resveratrol $\left(\mathrm{IC}_{50}=85.23 \pm 29.17 \mu \mathrm{M}\right)$, while the 3,5-dimethoxy-4-methylthio-trans-stilbene (22) exhibited higher cytotoxicity $\left(\mathrm{IC}_{50}=25.38 \pm 13.87 \mu \mathrm{M}\right)$. Thus it seems that toxicity of these compounds is related to the number of methoxy groups (Scheme 6).

\section{Antioxidant Activity of Resveratrol Derivatives}

As early as 1997, Fauconneau et al. [33] assessed the antioxidant activity of the flavonoids (anthocyanins, catechins) and non-flavonoids (stilbenes) by their capacity to prevent $\mathrm{Fe}^{2+}$-induced lipid peroxidation in microsomes and their action on $\mathrm{Cu}^{2+}$-induced lipid peroxidation in low-density lipoproteins. The results showed that the number and position of hydroxyl groups played an important role in the antioxidant activity of stilbenes.

Cai et al. [34] synthesized 4-hydroxy-trans-stilbene (4-HS), 3,4-dihydroxy-trans-stilbene (3, 4-DHS), 4, 4'dihydroxy-trans-stilbene (4, 4'-DHS) and 3, 5-dihydroxy-trans-stilbene (3, 5-DHS) and studied their antioxidant activity through the free radical-induced peroxidation of rat liver microsomes in vitro. They found that these derivatives are effective antioxidants against both AAPH- and iron-induced peroxidation in rat liver microsomes [34] [35]. Besides, they also found that the activity sequence follows the order: 3, 4-DHS > 4, 4'-DHS > resveratrol > 4-HS > 3, 5-DHS.

Caruso et al. [36] studied resveratrol and its analogues through ab initio calculations and crystal structure, the

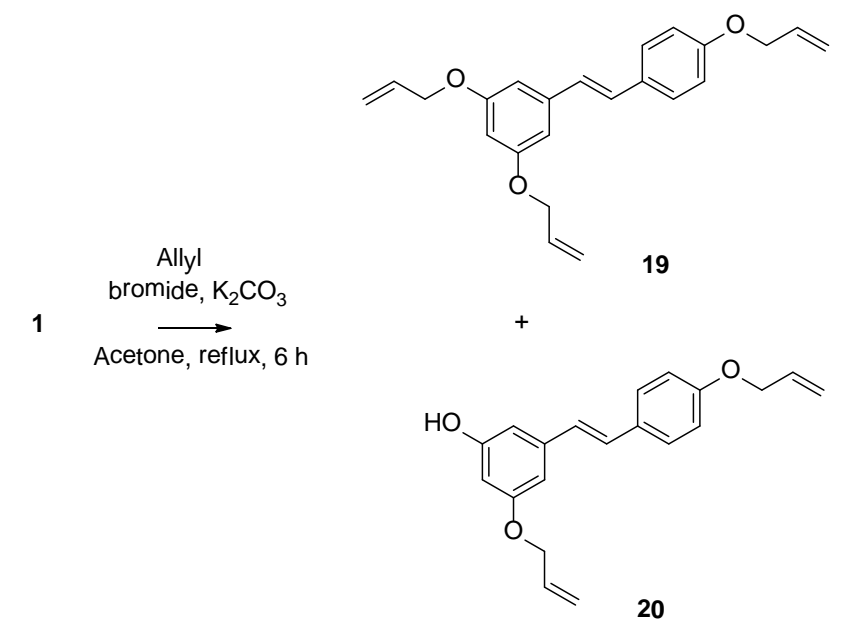

Scheme 5. Synthesis routes of compounds 19-20 according to Mulakayala et al. (2013).
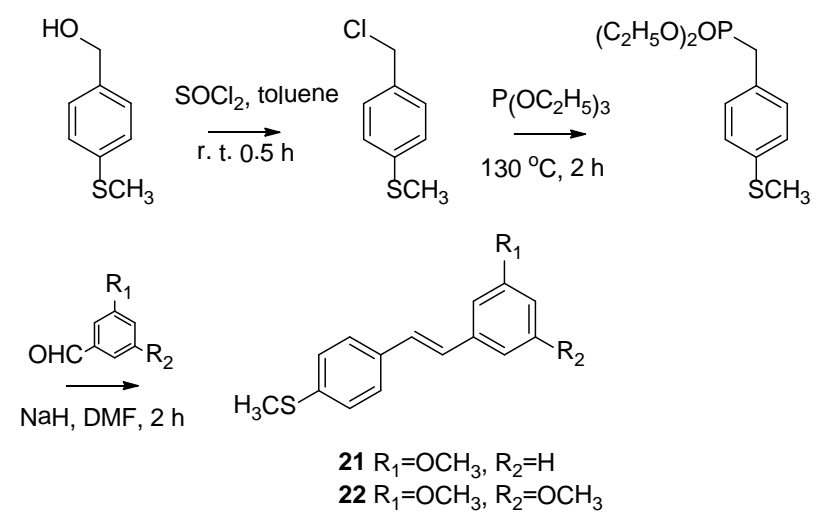

Scheme 6. Synthesis routes of compounds 21-22 (yield 40\% $47 \%$ ) according to Szaefer et al. (2014). 
results demonstrated that the $\mathrm{p}-4$ '-OH group is more acidic compared to the other two m-OH groups and $\mathrm{H}$-atom transfer is the dominant mechanism by which resveratrol and its derivatives scavenge free radicals.

In order to compare the antioxidant activity of the cis- and trans-resveratrol, Orallo [37] studied the possible in vitro effects of the resveratrol isomers on ROS (reactive oxygen species) and RNS (reactive nitrogen species) generation during the respiratory burst of thioglycollate-elicited rat peritoneal macrophages. The results revealed the cis isoform is less potent.

Stivala et al. [39] investigated the antioxidant activity of 6 resveratrol derivatives in vitro by measuring the inhibition of citronellal thermo-oxidation or the radical scavenging ability using the free radical DPPH. They found that reduction of the stilbenic double bond to single bond producing dihydroresveratrol leads to a lower antioxidant capacity when compared to resveratrol.

\section{Anti-Inflammatory Activity of Synthetic Resveratrol Derivatives}

In order to find new potent anti-inflammatory agents, Chen et al. [13] synthesized 17 resveratrol derivatives and tested them on xylene-induced mouse ear edema, the results indicated that compound 23 (Scheme 7) showed almost the same inhibition rate as resveratrol by $37.0 \%$. The study showed that resveratrol pyridyl-substituted analogs and the Mannich base displayed potent anti-inflammatory activity. Recently, Antus et al. [39] synthesized numerous derivatives to reveal the structural determinants of the molecule's activity. They investigated the anti-inflammatory properties of a new, triple-bond resveratrol analog, 3, 4, 5-trihydroxy-diphenylacetylene on lipopolysaccharide-stimulated RAW macrophages. They found that this compound exhibited better anti-inflammatory properties than resveratrol.

\section{Synthesis of Resveratrol Derivatives with Neuroprotective Effect}

Till now, there is no effective therapy for Alzheimer's disease (AD), the most common fatal neurodegenerative disorder. In order to reduce the risk of this neurodegenerative disorder, Lu et al. [40] synthesized and evaluated a novel series of resveratrol derivatives. They found that most of the synthetic compounds exhibited significant inhibition on self-induced $\beta$-amyloid (A $\beta$ ) aggregation and $\mathrm{Cu}$ (II)-induced $\mathrm{A} \beta_{1-42}$ aggregation. Especially, compounds 24 and 25 (Scheme 8) are potential lead compounds for $\mathrm{AD}$ therapy (24: $\mathrm{IC}_{50}=7.56 \mu \mathrm{M}$ and 25: $\mathrm{IC}_{50}=$

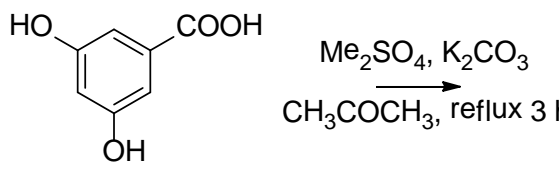<smiles>COC(=O)c1cc(OC)cc(OC)c1</smiles><smiles>CCOc1ccccc1</smiles><smiles>COc1cc(CO)cc(OC)c1</smiles>

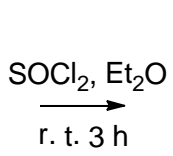<smiles>COc1cc(CCl)cc(OC)c1</smiles>

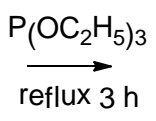<smiles>COCCO</smiles><smiles>CCOCCc1cccc(OC)c1</smiles>

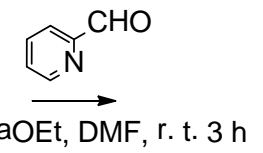<smiles>COc1cc(/C=C/c2ccccn2)cc(OC)c1</smiles>

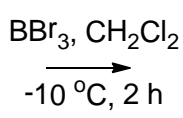<smiles>Oc1cc(O)cc(/C=C/c2ccccn2)c1</smiles><smiles>CCC(O)(C(=O)O)C(=O)OCCCl</smiles><smiles>CCOCCOc1cc(/C=C/c2ccccn2)cc(OCC(=O)OCC)c1</smiles>

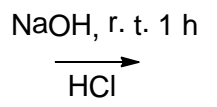<smiles>O=C(O)COc1cc(/C=C/c2ccccn2)cc(OCC(=O)O)c1</smiles>

Scheme 7. Synthesis routes of compound 23 (yield 69\%) according to Chen et al. (2005). 


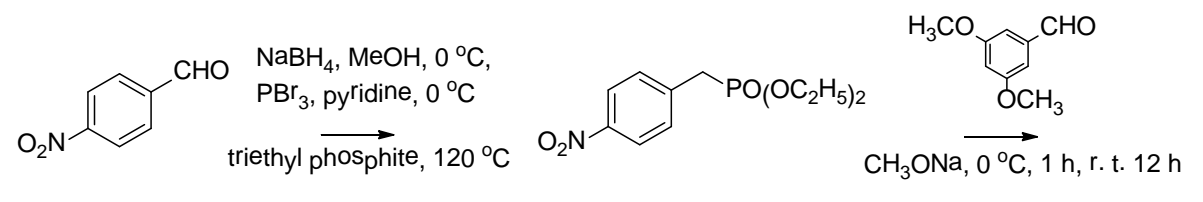<smiles>COc1cc(/C=C/c2ccc([N+](=O)[O-])cc2)cc(OC)c1</smiles><smiles>COc1cc(/C=C/c2ccc(NCc3cc(N(C)C)ccc3O)cc2)cc(OC)c1</smiles>

Scheme 8. Synthesis routes of compounds 24-25 (yield 58\% - 60\%) according to Lu et al. (2013).

$6.51 \mu \mathrm{M}$ for self-induced $\mathrm{A} \beta$ aggregation). Besides, compound 24 could cross the blood-brain barrier in vitro and did not exhibit any acute toxicity in mice at doses up to $2000 \mathrm{mg} / \mathrm{kg}$. The results gave us an insight into the neuroprotective effect of resveratrol derivatives.

\section{Concluding Remarks}

Resveratrol is a very interesting compound with its diverse potent biological activities. However, its poor water solubility and bioavailability limit its clinical application. Researchers assumed that resveratrol could be modified to agents with higher bioavailability and more pharmacologically active by chemical methods. Interestingly, despite that the bioavailability of resveratrol is low in vivo, there are numerous resveratrol-containing dietary supplements exhibiting stronger activity than resveratrol. Continued efforts towards the most active compounds mentioned in this review will be needed in order to expand resveratrol's SAR and its application to clinic.

\section{Acknowledgements}

This research was supported by the National Natural Science Foundation of China (No. 81273537), Scientific Research Fund of Hunan Provincial Education Department (No. 12K095), and the key disciplines of Hunan Province.

\section{Conflict of Interest}

The authors confirm that this article content has no conflicts of interest.

\section{References}

[1] Aggarwal, B.B., Bhardwaj, A., Aggarwal, R.S., Seeram, N.P., Shishodia, S. and Takada, Y. (2004) Role of Resveratrol in Prevention and Therapy of Cancer: Preclinical and Clinical Studies. Anticancer Research, 24, 2783-2840.

[2] Yan, Y., Gao, Y.Y., Liu, B.Q., Niu, X.F., Zhuang, Y. and Wang, H.Q. (2010) Resveratrol-Induced Cytotoxicity in Human Burkitt's Lymphoma Cells Is Coupled to the Unfolded Protein Response. BMC Cancer, 10, 445. http://dx.doi.org/10.1186/1471-2407-10-445

[3] Catalgol, B., Batirel, S., Taga, Y. and Ozer, N.K. (2012) Resveratrol: French Paradox Revisited. Frontiers in Pharmacology, 3, 141-158. http://dx.doi.org/10.3389/fphar.2012.00141

[4] Kelkel, M., Jacob, C., Dicato, M. and Diederich, M. (2010) Potential of the Dietary Antioxidants Resveratrol and Curcumin in Prevention and Treatment of Hematologic Malignancies. Molecules, 15, 7035-7074. http://dx.doi.org/10.3390/molecules15107035 
[5] Takaoka, M.J. (1940) Of the Phenolic Substances of White Hellebore (Veratrum grandiflorum Loe. fil.). J Faculty Sci Hokkaido Imperial University, 3, 1-16.

[6] Chen, Y.M., Hu, F., Gao, Y.H., Ji, N., Liu, W.Z. and Hua, E.B. (2014) Design and Synthesis of Resveratrol Analogs. Springer-Verlag, Berlin Heidelberg. http://dx.doi.org/10.1007/978-3-642-37925-3_146

[7] Mulakayala, C., Babajan, B., Madhusudana, P., Anuradha, C.M., Rao, R.M., Nune, R.P., Manna, S.K., Mulakayala, N. and Kumar, C.S. (2013) Synthesis and Evaluation of Resveratrol Derivatives as New Chemical Entities for Cancer. Journal of Molecular Graphics and Modelling, 41, 43-54. http://dx.doi.org/10.1016/j.jmgm.2013.01.005

[8] Simon, C., Britton, R.G., Cai, H., Gescher, A.J., Brown, K. and Jenkins, P.R. (2013) Novel Analogues of Resveratrol: Metabolism and Inhibition of Colon Cancer Cell Proliferation. Tetrahedron, 69, 6203-6212. http://dx.doi.org/10.1016/j.tet.2013.05.042

[9] He, S. and Yan, X.J. (2013) From Resveratrol to Its Derivatives: New Sources of Natural Antioxidant. Current Medicinal Chemistry, 20, 1005-1017. http://dx.doi.org/10.2174/0929867311320080004

[10] Frombauma, M., Clanche, S.L., Bonnefont-Rousselot, D. and Borderie, D. (2012) Antioxidant Effects of Resveratrol and Other Stilbene Derivatives on Oxidative Stress and NO Bioavailability: Potential Benefits to Cardiovascular Diseases. Biochimie, 94, 269-276. http://dx.doi.org/10.1016/j.biochi.2011.11.001

[11] Vilar, S., Quezada, E., Santana, L., Uriarte, E., Yánez, M., Fraiz, N., Alcaide, C., Cano, E. and Orallo, F. (2006) Design, Synthesis, and Vasorelaxant and Platelet Antiaggregatory Activities of Coumarin-Resveratrol Hybrids. Bioorganic \& Medicinal Chemistry Letters, 16, 257-261. http://dx.doi.org/10.1016/j.bmcl.2005.10.013

[12] Bertini, S., Calderone, V., Carboni, I., Maffei, R., Martelli, A., Martinelli, A., Minutolo, F., Rajabi, M., Testai, L., Tuccinardi, T., Ghidoni, R. and Macchia, M. (2010) Synthesis of Heterocycle-Based Analogs of Resveratrol and Their Antitumor and Vasorelaxing Properties. Bioorganic \& Medicinal Chemistry, 18, 6715-6724. http://dx.doi.org/10.1016/j.bmc.2010.07.059

[13] Chen, G.L., Shan, W., Wu, Y.L., Ren, L.X., Dong, J.H. and Ji, Z.Z. (2005) Synthesis and Anti-Inflammatory Activity of Resveratrol Analogs. Chemical and Pharmaceutical Bulletin, 53, 1587-1590. http://dx.doi.org/10.1248/cpb.53.1587

[14] Li, C., Fang, J.S., Lian, W.W., Pang, X.C., Liu, A.L. and Du, G.H. (2014) In Vitro Antiviral Effects and 3D QSAR Study of Resveratrol Derivatives as Potent Inhibitors of Influenza H1N1 Neuraminidase. Chemical Biology \& Drug Design, 85, 427-438.

[15] Galindo, I., Hernáez, B., Berná, J., Fenoll, J., Cenis, J.L., Escribano, J.M. and Alonso, C. (2011) Comparative Inhibitory Activity of the Stilbenes Resveratrol and Oxyresveratrol on African Swine Fever Virus Replication. Antiviral Research, 91, 57-63. http://dx.doi.org/10.1016/j.antiviral.2011.04.013

[16] Chalal, M., Klinguer, A., Echairi, A., Meunier, P., Vervandier-Fasseur, D. and Adrian, M. (2014) Antimicrobial Activity of Resveratrol Analogues. Molecules, 19, 7679-7688. http://dx.doi.org/10.1016/j.antiviral.2011.04.013

[17] Ogas, T., Kondratyuk, T.P. and Pezzuto, J.M. (2013) Resveratrol Analogs: Promising Chemopreventive Agents. Annals of the New York Academy of Sciences, 1290, 21-29. http://dx.doi.org/10.1111/nyas.12196

[18] Szekeres, T., Saiko, P., Fritzer-Szekeres, M., Djavan, B. and Jäger, W. (2011) Chemopreventive Effects of Resveratrol and Resveratrol Derivatives. Annals of the New York Academy of Sciences, 1215, 89-95. http://dx.doi.org/10.1111/j.1749-6632.2010.05864.x

[19] Richard, T., Pawlus, A.D., Iglésias, M.L., Pedrot, E., Waffo-Teguo, P., Mérillon, J.M. and Monti, J.P. (2011) Neuroprotective Properties of Resveratrol and Derivatives. Annals of the New York Academy of Sciences, 1215, 103-108. http://dx.doi.org/10.1111/j.1749-6632.2010.05865.x

[20] Li, F., Gong, Q., Dong, H. and Shi, J. (2012) Resveratrol, a Neuroprotective Supplement for Alzheimer’s Disease. Current Pharmaceutical Design, 18, 27-33. http://dx.doi.org/10.2174/138161212798919075

[21] Fuggetta, M. and Mattivi, F. (2011) The Immunomodulating Activities of Resveratrol Glucosides in Humans. Recent Patents on Food, Nutrition \& Agriculture, 3, 81-90. http://dx.doi.org/10.2174/2212798411103020081

[22] Lancon, A., Delmas, D., Osman, H., Thenot, J.P., Jannin, B. and Latruffe, N. (2004) Human Hepatic Cell Uptakeof Resveratrol: Involvement of both Passive Diffusion and Carrier-Mediated Process. Biochemical and Biophysical Research Communications, 316, 1132-1137.

[23] Walle, T., Hsieh, F., de Legge, M.H., Oatis Jr., J.E and Walle, U.K. (2004) High Absorption but Very Low Bioavailability of Oral Resveratrol in Humans. Drug Metabolism and Disposition, 32, 1377-1382. http://dx.doi.org/10.1124/dmd.104.000885

[24] Hoshino, J., Park, E.J., Kondratyuk, T.P., Marler, L., Pezzuto, J.M., van Breemen, R.B., Mo, S., Li, Y. and Cushman, M. (2010) Selective Synthesis and Biological Evaluation of Sulfate-Conjugated Resveratrol Metabolites. Journal of Medicinal Chemistry, 53, 5033-5043. http://dx.doi.org/10.1021/jm100274c

[25] Manna, S.K., Mukhopadhyay, A. and Aggarwal, B.B. (2000) Resveratrol Suppresses TNF-Induced Activation of Nuc- 
lear Transcription Factors NF- $\kappa$ B, Activator Protein-1 and Apoptosis: Potential Role of Reactive Oxygen Intermediates and Lipid Peroxidation. The Journal of Immunology, 164, 6509-6519. http://dx.doi.org/10.4049/jimmunol.164.12.6509

[26] Tsai, S.H., Lin-Shiau, S.Y. and Lin, J.K. (1999) Suppression of Nitric Oxide Synthase and the Down-Regulation of the Activation of NF- $\kappa$ B in Macrophages by Resveratrol. British Journal of Pharmacology, 126, 673-680. http://dx.doi.org/10.1038/sj.bjp.0702357

[27] Fresco, P., Borges, F., Diniz, C. and Marques, M.P. (2006) New Insights on the Anticancer Properties of Dietary Polyphenols. Medicinal Research Reviews, 26, 747-766. http://dx.doi.org/10.1002/med.20060

[28] Minutolo, F., Sala, G., Bagnacani, A., Bertini, S., Carboni, I., Placanica, G., Prota, G., Rapposelli, S., Sacchi, N., Macchia, M. and Ghidoni, R. (2005) Synthesis of a Resveratrol Analogue with High Ceramide-Mediated Proapoptotic Activity on Human Breast Cancer Cells. Journal of Medicinal Chemistry, 48, 6783-6786. http://dx.doi.org/10.1021/jm050528k

[29] Ruan, B.F., Huang, X.F., Ding, H., Xu, C., Ge, H.M., Zhu, H.L. and Tan, R.X. (2006) Synthesis and Cytotoxic Evaluation of a Series of Resveratrol Derivatives. Chemistry \& Biodiversity, 3, 975-981. http://dx.doi.org/10.1002/cbdv.200690106

[30] Liu, H.C., Dong, A.J., Gao, C.M., Tan, C.Y., Liu, H.X., Zu, X.Y. and Jiang, Y.Y. (2008) The Design, Synthesis, and Anti-Tumor Mechanism Study of N-Phosphoryl Amino Acid Modified Resveratrol Analogues. Bioorganic \& Medicinal Chemistry, 16, 10013-10021. http://dx.doi.org/10.1016/j.bmc.2008.10.022

[31] Liu, Q., Jin, W.W., Zhu, Y., Zhou, J.Y., Lu, M. and Zhang, Q. (2012) Synthesis of 3'-Methoxy-E-Diethylstilbestrol and Its Analogs as Tumor Angiogenesis Inhibitors. Steroids, 77, 419-423. http://dx.doi.org/10.1016/j.steroids.2011.12.024

[32] Szaefer, H., Cichocki, M., Krajka-Kuźniak, V., Stefański, T., Sobiak, S., Licznerska, B. and Baer-Dubowska, W. (2014) The Effect of Resveratrol and Its Methylthio-Derivatives on NF- $\kappa$ B and AP-1 Signaling Pathways in HaCaT Keratinocytes. Pharmacological Reports, 66, 732-740. http://dx.doi.org/10.1016/j.pharep.2014.03.012

[33] Fauconneau, B., Waffo-Teguo, P., Huguet, F., Barrier, L., Decendit, A. and Merillon, J.M. (1997) Comparative Study of Radical Scavenger and Antioxidant Properties of Phenolic Compounds from Vitis Vinifera Cell Cultures Using in vitro Tests. Life Sciences, 61, 2103-2110. http://dx.doi.org/10.1016/S0024-3205(97)00883-7

[34] Cai, Y.J., Fang, J.G., Ma, L.P., Yang, L. and Liu, Z.L. (2003) Inhibition of Free Radical-Induced Peroxidation of Rat Liver Microsomes by Resveratrol and Its Analogues. Biochimica et Biophysica Acta (BBA)-Molecular Basis of Disease, 1637, 31-38. http://dx.doi.org/10.1016/S0925-4439(02)00174-6

[35] Queiroz, A.N., Gomes, B.A., Moraes, W.M. and Borges, R.S. (2009) A Theoretical Antioxidant Pharmacophore for Resveratrol. European Journal of Medicinal Chemistry, 44, 1644-1649. http://dx.doi.org/10.1016/j.ejmech.2008.09.023

[36] Caruso, F., Tanski, J., Villegas-Estrada, A. and Rossi, M. (2004) Structural Basis for Antioxidant Activity of TransResveratrol: Ab Initio Calculations and Crystal and Molecular Structure. Journal of Agricultural and Food Chemistry, 52, 7279-7285. http://dx.doi.org/10.1021/jf048794e

[37] Orallo, F. (2006) Comparative Studies of the Antioxidant Effects of Cis- and Trans-Resveratrol. Current Medicinal Chemistry, 13, 87-98. http://dx.doi.org/10.2174/092986706775197962

[38] Stivala, L.A., Savio, M., Carafoli, F., Perucca, P., Bianchi, L., Maga, G., Forti, L., Pagnoni, U.M., Albini, A., Prosperi, E. and Vannini, V. (2001) Specific Structural Determinants Are Responsible for the Antioxidant Activity and the Cell Cycle Effects of Resveratrol. The Journal of Biological Chemistry, 276, 22586-22594. http://dx.doi.org/10.1074/jbc.m101846200

[39] Antus, C., Radnai, B., Dombovari, P., Fonai, F., Avar, P., Matyus, P., Racz, B., Sumegi, B. and Veres, B. (2014) Anti-Inflammatory Effects of a Triple-Bond Resveratrol Analog: Structure and Function Relationship. European Journal of Pharmacology, 748, 61-67.

[40] Lu, C.J., Guo, Y.Y., Yan, J., Luo, Z.H., Luo, H.B., Yan, M., Huang, L. and Li, X.S. (2013) Design, Synthesis, and Evaluation of Multitarget-Directed Resveratrol Derivatives for the Treatment of Alzheimer's Disease. Journal of Medicinal Chemistry, 56, 5843-5859. http://dx.doi.org/10.1021/jm400567s 